\title{
POPULATION PRESSURE, HOUSING, AND HABITAT
}

\author{
JOSEPH J. SPENGLER*
}

[F]or life to run smoothly, for the living organism to remain healthy in the highest degree, the environmental complex must be made as perfect as possible.

$$
\text { -J. W. Bews, Human Ecology } 79 \text { (1939). }
$$

Woe unto them that join house to house, that lay field to field, till there be no room.

-Isaiah 5:8.

Very few people, indeed, want to be better than they are; or . . . hunger and thirst after righteousness.

-T. S. Eliot, Essays, Ancient and Modern II5-16 (1936).

\section{INTRODUCTTON}

A house is not a home. This aphorism is usually held to possess validity only in the demimonde. Brief consideration suggests, however, that the validity of this aphorism is not so confined. It fits other worlds as well; in particular, the world of housing upon which the current issue of this journal is focused.

It may still be true in this age of insecurity, anti-privacy, and emerging police states, that "the house of everyone is to him," as Sir Edward Coke declared four centuries ago, "as his castle and fortress, as well for his defense against injury and violence as for his repose." It is also true that a man's house means a great deal more, even to those who agree with Samuel Butler that occasional absence from one's house enhances its attractiveness.

In this article I argue (a) that the subject of housing must be examined in terms of the larger set of gesellschaftliche and gemeinschaftliche relations within which the house, together with its occupying household, is situated; (b) that this set of relations and hence the role of housing is significantly affected by the growth and concentration of population, control of which is essential to the easing of the so-called housing problem.

The underlying issue is clearly recognized by architects such as Doxiadis who see in the expansion of the impersonal city and the associated elimination of nature a process that is destroying neighborhood and community units and making of man a building-occupying troglodyte subject to "instructions issued from the peak of the pyramid." He suggests that we once again create human communities in our cities, "operating neighborhoods, downtown shopping centers where people can walk freely, can come into natural contact, can enjoy quiet surroundings and create and admire art. These human communities should become the cells which will be interconnected

- A.B. 1926, M.A. I929, Ph.D. 1930, Ohio State University. James B. Duke Professor of Economics, Duke University. 
by mechanical means of transportation and communications to form major systems and major cities."1 While Doxiadis is here referring mainly to communities within large cities he recognizes the interrelation of housing and community and the importance of how man can spend his time, especially in a modern world in need of a moral equivalent to work.

Home Versus House

How the Greeks, Aristotle in particular, viewed housing may be suggestive since concern for the eudaemonic aspect of life played a very important role in their view of housing-a concern honored more in the breach than in the observance in the United States. ${ }^{2}$ Aristotle approaches housing in terms of the overall community and the pursuit of the "highest good." The polis, or city state, as he conceived of it, was a community which, embracing all other communities, aimed at the "highest good." The elemental community of which the state was composed was the household, to whose management Aristotle and those influenced by him devoted attention. ${ }^{8}$ Aristotle, defender of simplicity in a simple age, pointed to the smallness of the number of instruments needed within a household to make the "good life" possible. Presumably he agreed with Hesiod that a house was the "first and foremost" requisite of a household" and with the statement that "a house must be arranged both with a view to one's possessions and for the health and well-being of its inhabitants." A house must, therefore, "be airy in summer and sunny in winter"; whence it needs to face "north" and be longer than wide. ${ }^{6}$ These and other aspects of a house were stressed several centuries later by the architect Vitruvius, a contemporary of Nero, who designed and situated several types of houses to meet specific occupational and climatic requirements.

Aristotle looked upon a house as one of a triad of interrelated elements: house, household, and organic urban community. The house sheltered the members of the household and afforded them access to a good and healthy life. The household itself was relatively self-sufficient, as a rule. The head of a household was united with other household heads in that network of reciprocity which undergirded the state or urban community.

The problems confronting a household in Aristotle's day were fewer and simpler than those confronting a household in the affluent present. Cities usually were small

\footnotetext{
${ }^{1}$ Doxiadis, Topics: Of Inhuman and Human Cities, N.Y. Times, March II, 1967, at 28, col. 5. See generally on gemeinschaft and gesellschaft, T. PArsons, STRUcrure of Socist Action 686-94 (1937).

2 See, e.g., R. E. Wycherly, How the GreEks BuIlt Cities (2d ed. I962).

${ }^{3}$ Politica I:2. See generally Oeconomica x:r, a work partly Aristotelian and partly reflective of the influence of Xenophon and others.

Pozitica I:8-9.

${ }^{8}$ Oefonomica $\mathrm{i}: 2$.

'Id. at $\mathrm{x}: 6$

${ }^{7}$ Vitruvius, The TEN Books on ARchitecture 24-26, 38-4I, 170-92 (M. H. Morgan transl, I960).
} 
and relatively free of congestion, even of that congestion of which Juvenal was later to complain in Imperial Rome. Getting to work, to recreational and religious centers, or to political responsibilities, presented no serious difficulties. Aristotle wanted to keep the Greek city that way. Not only did he insist that a city not be large, since "a very populous city can rarely, if ever, be well governed." He even suggested that its population not exceed "the largest number which suffices for the

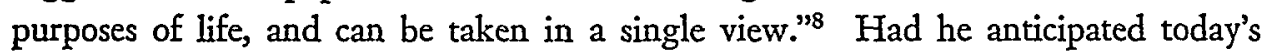
opulent society, he would have found it wanting, along with its conception of housing.

The observations made by Aristotle or imputable to him call attention to the fact that a house is not a solitary, autonomous, self-subsisting unit, even when occupied by a household, but rather a locus in many partially overlapping environments or complexes. It is a locus in the spatial economy of the household; it is a locus in a social environment; it is a locus in a physical environment that varies in salubrity and conduciveness to health. In the parlance of today, we may conceive of a house as a micro-habitat within a larger but highly relevant macro-habitat. The householder may be said to dwell in the former and carry on his extra-dwelling roles and functions in the latter. It is quite evident, therefore, that his well-being and the extent to which he can attain the good life depend in large measure upon the quality of each of these two habitats. This inference is borne out by data assembled on the amounts of time spent by various types of families, upon in-home and extra-house activities, respectively. ${ }^{9}$

Since a house is a micro-habitat within a macro-habitat, it is improper to conceive of housing independently of and in isolation from the macro-habitat within which houses are situated. To do so is on a par with conceiving of Gettysburg in terms of Edward Everett's prolix but forgotten oration. That housing often is so conceived of is a result of the absence of order, or even of ordering values, from the determinants of the growth, organization, and construction of cities. The outcomes resulting are accepted as parts of the scheme of things, with the result that the fundamental significance of the macro-habitat for the quality of housing is underestimated. In consequence, the impact of the growth and concentration of population upon man's macro- and micro-habitats receives little attention.

\section{II}

\section{The Macro-Habitat}

The macro-habit, within which household, house, and micro-habitat are situated, embraces a number of environments. For purposes of illustration we need discuss only a few. Perhaps the most important is the set of spatial economies within which the individuals composing a household seek the good life, directly and/or indirectly

\footnotetext{
${ }^{8}$ Polirica 7:4.

${ }^{\circ}$ E.g., the excellent account given in J. N. Morgan, I. A. Seragetdin \& N. Baerwaldt, Productive Americans (1966).
} 
through pursuit of material means. Almost equally important are the social, physical, and health environments of the micro-habitat. It is sometimes said, of course, that modern man has become largely free of his external environment. ${ }^{10}$ This exaggerated view suggests a modern Daedalus who pretends to have risen above his physical environment. One must, therefore, agree with Dubos's comment: "As happened to Antaeus of the Greek legend, his [man's] strength will probably wane if he loses contact with the biological ground from which he emerged and which still feeds him, physically and emotionally."11

A house is always a locus of household activities and a base from which members of a household operate. The household is situated in a net of activity-loci interrelated from the vantage point of members of a household even if not always connected by exchange as are interrelated markets. Each member of a household moves from his house to a locus of activity and back to his house either directly or via a path connecting diverse activities participated in sequentially. The problem confronting each member of a household is that of minimizing time utilized in moving from house to activity, from activity to activity, and from activity to house. His capacity to minimize time thus expended is quite limited, however, since the loci of these activities, together with the house, are not easily modified. ${ }^{12}$

Economy of time must be mainly sought, therefore, via economy of space, though some economy of time is achievable through reducing the actual time cost if not also the pecuniary cost of traversing space. Economy of space in turn must be sought through optimizing the spatial arrangement of relevant activities in the urban environs of the house and household. ${ }^{13}$ When this is done a house begins to be viewed as a home, as the focus of man's search for the good life. This outcome is not likely to be emphasized, however, until both social scientists and those who manage the allocation of resources become space-minded-concerned about terrestrial and urban space rather than about mere lunar and martian space. For, as Isard observes, excessive emphasis upon time in economic analysis long made for neglect of the role of space in the theoretical and empirical structures of Anglo-Saxon economists. ${ }^{14}$

What constitutes a satisfactory social environment is not easy to define or to realize empirically. It is evident, however, that occupants of micro-habitats or

\footnotetext{
${ }^{10}$ For example, R. W. Gerard writes: "Man has, in fact, largely cut himself off from the external environment and created a hothouse internal environment of culture in which he lives in remarkable physical comfort. ... O Our lives are spent overwhelmingly at the symbolic level, and we live in a manmade sea of meanings. And the sea is still rising more or less exponentially." Gerard, Intelligence, Information, and Education, 148 Scr. 762,763 (1965).

12 R. Dubos, Man Adapting 279 (1965).

${ }^{12}$ An extended inquiry into the relationships between time, space, and activity is being conducted by G. C. Hemmens. A recent progress report is available: The Structure of Urban Activity Linkages, 1966 (mimeo., Center for Urban and Regional Studies, University of North Carolina, Chapel Hill).

${ }^{18}$ W. ISARd, Location and SPace-Economy (1956).

${ }^{14} 1 d$. at $24-27$.
} 
neighborhoods are not likely to agree upon what makes a social environment satisfactory unless they agree on many things. This condition is overlooked, of course, in much of the discussion of housing that involves the intermingling of households which are quite dissimilar in tastes and conduct-determining norms. Even within a household common standards of value must be present to permit passage from the preference patterns of its individual members to a preference pattern representative of the household as such. ${ }^{15}$ At the neighborhood level where the tastes of individuals must be sufficiently similar to permit the construction of "suitable social welfare functions,"16 a minimal though not excessive degree of similarity of tastes is essential to insure agreement on what constitutes a satisfactory social environment. The degree required is less when there is agreement both on the need for day-to-day decisions and on the mechanism or process whereby these decisions are reached. ${ }^{17}$ The market mechanism alone is unlikely to bring about this minimal degree under all conditions, though it can be enabled to do so if certain conditions are met. ${ }^{18}$ It is true, as a rule, therefore, that a considerable though variable degree of homogeneity in the tastes of those inhabiting a neighborhood or macro-habitat is essential to their settling upon what makes a social environment good. When this degree is not fully attained, whether because of class or other differences, the macro-habitat becomes instable. ${ }^{19}$ It can become instable also if the inhabitants and their children become too standardized.

While it appears to be true that whatever unduly reduces the degree of homogeneity of any particular neighborhood or macro-habit affects it unfavorably, this inference does not support the view that cultural differences between macro-habitats should be reduced. There must be room in the all-inclusive community for a sufficiency of diversity which, while a characteristic of individuals, is in part a concomitant of differences between macro-habitats. ${ }^{20}$ It may be well, therefore, that the overall community resemble a sea dotted with islands which differ culturally from one another. ${ }^{21}$ Unfortunately, the "formal elegance of welfare economics"

\footnotetext{
${ }^{16}$ K. J. ARrow, Social Chorce and Individual Values 9 n.I (Cowles Comm'n for Research in Economics Monograph No. I2, I95I).

${ }^{10} \mathrm{Id}$. at 8x. "[I]t must be demanded that there be some sort of consensus on the ends of society, or no social welfare functions can be performed." Id. at 83 .

${ }^{27}$ Arrow concludes that "we may expect that social welfare judgments can usually be made when there is both a widespread agreement on the decision process and a widespread agreement on the desirability of everyday decisions." Id. at $9 \mathrm{r}$.

${ }^{18}$ The market mechanism does not always take into account all relevant matters, although it can be manipulated to this end. See Arrow's discussion, id. at $8 \mathrm{I}-86$.

${ }^{10}$ For example, a retirement city built outside Sacramento for retired military personnel proved a flop. "[I]t turned out that retired colonels did not like to live beside retired sergeants, and neither liked the idea of living on streets named Billy Mitchell Boulevard and Hap Arnold Court." Fortune, Feb. 1966, at 158 .

${ }_{20}$ See generally Platt, Diversity, I54 ScI. Ir32 (I966), for a discussion stressing the importance of cultural and other diversity.

${ }^{21}$ In the United States, for example, though unifying common values are present, there are also many local communities which, though they include diverse elements, have evolved each into a somewhat unique constellation of values and institutions. See, e.g., R. E. Engler, JR., The Challenge of Diversity (rg64).
} 
does not tell us how much homogeneity is essential to a people's happiness. ${ }^{22}$

It may be noted parenthetically that economic as well as social factors have to be taken into account if the current housing shortage confronting nonwhites is to be greatly reduced. For, while housing values in nonwhite areas tend to lie below those for comparable housing in nearby white areas, ${ }^{23}$ and while block-busting can enlarge nonwhite housing areas, urban renewal programs tend to raise the price of affected urban land above the level at which it is economically attractive to most nonwhites. ${ }^{24}$ Emphasis upon residential desegregation, it is said, is retarding the construction of low-income housing. ${ }^{25}$

The degree of attractiveness of the physical environment of a macro-habitat $\mathrm{cn}$ veloping a dwelling unit depends upon many circumstances, some of which seem to have been taken into account even in ancient ghetto-ridden Egypt. ${ }^{20}$ Among these circumstances are absence of disorder and traffic congestion, the availability of private and public space, and general attractiveness, now usually lacking within as well as outside American urban centers. ${ }^{27}$ Closely related is the healthfulness of this environment and its freedom from noise and pollution both of which are inimical to good health. ${ }^{28}$

An environment's healthfulness usually depends, at least in advanced countries, upon its freedom from pollution, especially chemical pollution of the water and the atmosphere. "[T]he few facts available demonstrate," René Dubos states, "that

\footnotetext{
${ }^{22}$ Mishan, A Survey of Welfare Economics, r939-59, in I Surveys op Economic Theory 154, $211-13$ (American Economic Ass'n \& Royal Economic Soc'y 1965).

${ }^{23}$ Bailey, Effects of Race and of Other Demographic Factors on the Values of Single-Family Homes, 42 LAND Econ. 215 ( 1966 ).

24 See J. Rothenberg, Economic Evaluation of Urban Renewal (1967); Bailey, Note on the Economics of Residential Zoning and Urban Renewal, 35 LAND EcoN. 288 (1959); Nourse, The Economics of Urban Renewal, 42 LAND Econ. 65 (I966).

${ }^{28}$ "The Achilles heel of housing programs has been precisely our insistence that better housing for the black poor be achieved by residential desegregation. This ideal glosses over the importance of the ethnic community as a staging area for groups to build the communal solidarity and power necessary to compel eventual access to the mainstream of urban life. . . .

"If group conflict is at the root of past failures, strategies must be found to improve ghetto housing without arousing the ire of powerful segments of the white community." Piven \&6 Cloward, Desegregated Housing, Who Pays for the Reformers' Ideal?, New Republic, Dec. 17, 1966, at I7, 21. That this proposal for the improvement of ghettos is not impractical is suggested by the actions of a number of large building supply companies that are rebuilding parts of slums, to be turned over to nonprofit sponsors, and by plans to establish corporations that can produce housing competitive with public housing. See Ridgeway, Rebuilding the Slums, New Republic, Jan. 7, I967, at 22.

${ }^{20}$ Perhaps the world's first model village for workmen was that built in Amarna in Egypt in the I4th century, B.C. See E. Wells, Nefertiti 162-63 ( 1964$)$.

${ }^{27}$ See L. Halprin, Freeways (I966); Faltermayer, How to Wage War on Ugliness, Fortune, May 1966, at r30; Larremore, Public Aesthetics, 20 HArv. L. Rev. 35 (1906). See generally R. Stanr, TuE Living End: The Crry and Irs Critics (1966); Spengler, The Aesthetics of Population, r3 Population BuLL. 6I (I957).

${ }^{28}$ See generally on the adverse effects of noise, Beranek, Noise, Scientific AM., Dec. 1966, at 66; Kryter, Psychological Reactions to Aircraft Noise, I5I Scr. 1346 (1966); Silence at Less than \$35 an Ounce, Fortune, Dec. 1966, at 191; When Noise Annoys, Time, Aug. 19, 1966, at 24, and on the destructiveness of the "sonic boom," offset only by an increase in the egg-hatching rate among chickens, THE NEW YORKER, Dec. 18,1965 , at 4 I.
} 
pathological states can be caused by exposure to concentrations of pollutants of the order of those which exist in the urban atmosphere. On the basis of these results, it can be surmised that pollution can also have deleterious and lasting effects on human beings."29 "The possibility of delayed and cumulative effects is not limited to any particular class of agent." 30 Dubos, therefore, stresses the "need for striking information" because "environmental pollution will not be controlled until physicians and scientists take an active part in its study."31 Response to this same need on the part of students of urban and housing environments will help place efforts to solve housing problems in a more general context than is common at present; if will help men recognize that since, as Commoner shows, the elements of nature constitute an integrated totality, ${ }^{32}$ it must be dealt with as a whole and not in a piecemeal fashion..$^{33}$

\section{III}

\section{Population Trends}

The rate of population growth has fallen below 1.5 per cent per year, at which rate it increased in $1960-64$ when natural increase accounted for eighty-seven per cent of the total growth. Natality has since descended enough to reduce the current rate of natural increase nearly to one per cent per year. In the years just ahead, however, the large increase in the number of females aged 20-29, an echo of the upsurge of natality after the war, should push natality up somewhat. It is likely that the nation's population, nearly 198 million at the beginning of 1967 , will number over $25^{\circ}$ million by 1985 and 300 million or more by the close of the century. Should this population continue thereafter to grow $I \frac{1}{4}$ per cent per year it would number a billion or more by the year 2100 , by which time population density might exceed 350 per square mile in the conterminous United States. Acres of all sorts per person would then average less than two.

The nonwhite population will increase somewhat faster than the white population, rising from twelve per cent of the total at present to about 13.5 per cent by 1985 . At that time the rate of natural increase of the nonwhite population may be somewhat in excess of two per cent whereas the white rate will be about $I^{1 / 3}$ per cent. Should that rate differential persist, around one-fourth of the nation's population would be nonwhite by 2085 .

\footnotetext{
${ }^{20}$ Dubos, supra note II, at 209-10. See generally Environmental Poliution Panel, President's Science Advisory Commitiee, Restoring the Quality of Our Environment I-9, 9i-tor (Report of the Environmental Pollution Panel, I965).

${ }^{80}$ Dubos, supra note II, at 22I. See generally B. Commoner, Science and Survivar (I966); Ecology, Tume, Jan. 27, 1967, at 48 .

1 Dubos, supra note II, at 225. (Emphasis added.)

sa Commoner, supra note 30 .

33 See, e.g., Committee on Pollution, National Research Council, National Academy of Sciences, Pub. No. I400, Waste Management and Control (1966); Subcomm. on Science, Research, and Development, House Comm. on Science and Astronautics, 89th Cong., 2D Sess., Environmental Pollution-A Challenge To Science and Technology (Comm. Print ig66).
} 
While the farm population has continued to decline, from 32 million in I920 to less than 12 million, increase in population concentration has been extensive rather than intensive. The population formerly defined as rural has continued to increase, though only about half as fast as the nation's population-in 1940-60 about sixteen per cent instead of thirty-five per cent as in the aggregate. The urban population increased more rapidly, of course, about fifty-two per cent; that in places under I00,000 increased about seventy-one per cent while that in places of 100,000 and over grew about thirty-four per cent. Even so, the proportion which the population in places of over 100,000 constituted of the total population changed only slightly. ${ }^{34}$ The data just presented do not, however, fully reflect the implosion and megalopolitanization of population in process. But they do reveal how a shifting urban frontier has replaced that westerly moving rural frontier in terms of which some seventy years ago Frederick Jackson Turner interpreted the course of American history up to the r8gos. For a real sense of the change we must turn to metropolitan data.

Continuing population growth may intensify population concentration and urban crowding in two ways. First, it may simply add to the population situated in places of all sizes. Second, should the population-attracting power of cities increase more than in proportion to their numerical size, the rate of growth will be greatest in larger centers and the fraction of the nation's population concentrated therein will increase. This did happen between 1900 and 1930 when the rural fraction of the population fell from 60.3 per cent to 43.8 per cent and when the population in places of 100,000 and over rose from 18.7 to 29.6 per cent of the total population and from 47.1 to 52.7 per cent of the urban population. Then the process slowed down. Between I930 and 1950 none of these percentages changed markedly. More recently some dispersion has set in. Between $195^{\circ}$ and 1960 the fraction of the nation's population situated in places of both above 500,000 and above 100,000 declined. This increase in dispersion may reflect in part a forty-two per cent increase in 1940.60 in the number of places under 100,000- of which nearly three-fifths were added in $1950-60 .{ }^{35}$

Whether an increasing fraction of the nation's population does become concentrated in the larger centers turns on the strength of the stochastic process apparently underlying what Kendall, describing the work of Zipf and others, calls "a kind of the-higher-the-fewer rule." This rule "says, in effect, that for certain kinds of activity with a measurable size $x$, the number $y$ of individuals greater than or equal to $x$ is given by

$$
y=A / x^{p}
$$

\footnotetext{
${ }^{34}$ In $1940,28.8$ per cent of the total population and 5 I per cent of the urban population lived in places of 100,000 and over. The corresponding percentages in 1960 were 28.4 and 45 . I have used the former census definition of "urban" in order to make the data of 1940 comparable with those of 1950 and I960.

${ }^{35}$ U.S. Buread of the Census, Dep't of Commerce, Statistical Abstract of the United States I965, at I5 (I965); C. Taeuber \& I. B. Taeuber, The Changing Population of the United States II4-15, II8 (1958).
} 
where $p$ is a constant which is often quite close to unity."36 Here $y$ stands for the rank of a particular city in size of population, $x$ for its size, and $p$ and $A$ are constants, with $A$ denoting the population of the largest center and $p$ approximating unity. Now if $A$ grows faster than a nation's population it will, after the manner of a Saturn eating his own children, increase at the expense of other communities, especially the smaller ones; ${ }^{37}$ but if the number of communities grows rapidly enough, the population will tend to become more dispersed. ${ }^{38}$

It is within the metropolitan population that we find changes taking place of great significance for housing and its macro-habitats. First, the population of metropolitan areas is growing much faster than that lying outside these areas-2.3 per cent per year in the I950s and $x .9$ per cent per year in $1960-65$ when the corresponding rates for the nonmetropolitan population were 0.8 and 0.7 per cent per year. The fraction of the nation's population living in metropolitan areas rose from about 60.5 per cent in I950 to about sixty-three per cent in I960 and sixty-four per cent in 1965. The metropolitan population in Ig60 already approximated nine-tenths of the urban population and it could easily rise to seventy-five per cent of the nation's total population within $40-5^{0}$ years. Second, while the proportion of the nation's population growth taking place in metropolitan areas is greater than before the Second World War, the proportion taking place in central cities situated within metropolitan areas is declining, especially in those with over a million inhabitants. ${ }^{39}$ In sum, while the nation's population is becoming more concentrated, within the larger areas of concentration a redistribution of population is taking place and thus changing or threatening to change many of the macro-habitats within which housing is located. The rate of change underway can be especially significant because it is made up of net in-migration as well as of natural increase. For example, between I950 and I960 about thirty-five per cent of the increase in metropolitan population was due to in-migration. ${ }^{40}$

The long continued migration of the Negro to the city in search of better economic opportunity and housing, coupled with the decline in foreign immigration, is bringing about a redistribution of population within metropolitan centers. ${ }^{41}$ This redistribution is of very great significance for housing problems since in ${ }^{2} 6_{5}$ about sixty-four per cent of the white population of the United States and about sixty-eight per cent of the nonwhite population lived in metropolitan areas. This

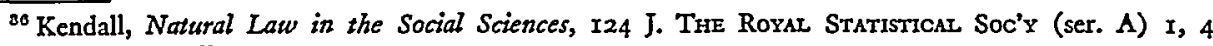
(196I). See generally IsARD, supra note 13 , at 55 .

${ }^{87}$ G. K. Zipf, Natronal UNITY AND Disunity 55 (I94I). In the United States the ratio of New York's population to that of the nation rose between $I 880$ and 1930 and thereafter fell. Id. at 56 . I have computed the ratios for 1950 and 1960 .

${ }^{88}$ The ratio of places to population rose from 100 in 1900 to 115 in 1930,118 in 1940 , and 126 in I960.

${ }^{80}$ W. S. Thompson \& D. T. Lewis, Population Problems I4T-48, 156 (5th ed. 1965 ).

$10 \mathrm{Id}$. at I5I-52.

"See Newman, The Negro's Journey to the City (pts. I \& 2), 88 MoNTHLy Labor Rev. 502, 644 (1965).
} 
redistributive process reflects forces affecting both concentration and congestion as well as the passage of a city's racial composition beyond a so-called tipping point. ${ }^{42}$ First, the population outside the central cities has been growing much faster than that in these cities, four per cent per year in $1950-60$ and 3.3 per cent per year in 1960-65 compared with annual increases in central cities of one per cent in the I950s and 0.6 per cent in 1960-65. Second, the nonwhites are displacing the whites in central cities with the result that if this process continues, by I 980 seven or more large cities will be predominantly nonwhite (mainly Negro) and perhaps thirty more about one-third nonwhite. Of the top ten cities in the United States only Houston and Los Angeles will be predominantly white thirty-five years from now. ${ }^{43}$

Illustrative of current redistributive tendencies are those of $1960-65$ when the nonwhite population of metropolitan areas increased 2,508 thousand, of whom 2,096 thousand settled in central cities. Meanwhile, the metropolitan white population increased 8,982 thousand, all of whom settled outside central cities, together with about 470 thousand who migrated there on balance from central cities. The nonwhite fraction of the total central-city population thus rose from about eighteen per cent in 1960 to nearly twenty-one per cent in 1965 ; in 1950 it was only about thirteen per cent. ${ }^{44}$ Meanwhile the nonwhite fraction of the metropolitan population in the ring of areas outside central cities, about 5.5 per cent in 1950 , had declined to five per cent by I960. An unpublished study of eleven central cities, by my colleague Reynolds Farley, indicates that residential segregation is again increasing.

So alarmed has the present administration apparently become at the current drift and its implications for desegregation of the school system that what amount to legislative and administrative efforts to countervail or reverse the drift are being initiated. ${ }^{45}$ This approach not only is unmindful of potential boomerang effects; it overlooks the advantages to be had from the proposal made below to multiply the number of urban centers to which Negro and white can migrate and through which the problem of concentration can be greatly alleviated, though not solved altogether.

\section{IV}

\section{Population Efrects}

The effects of the population trends described in the preceding section are of two sorts, sequelae to population growth and sequelae to population concentration. Four

\footnotetext{
12 See, e.g., Grodzins, Metropolitan Segregation, ScIENrrfic Am., Oct. 1957, at 33; Tauber \& Taubcr, White Migration and Socio-Economic Differences Between Cities and Subtrbs, 29 AM. Socrozocical. REv. 718 (1964); Winsborough, An Ecological Approach to the Theory of Suburbanization, 68 Am. J. Sociology 565 (1963); Winsborough, City Growth and City Structure, J. Regronal Sci., Winter 1962, at 35.

${ }^{8}$ U.S. News \& World Report, Feb. 2I, 1966, at 72-73; U.S. News \& World Report, March 6, 1967 , at $58-62$.

14 The fraction that was Negro was slightly smaller than the nonwhite. See generally on the suburbanization process, Winsborough, An Ecological Approach to the Theory of Suburbanization, supra note 42.

${ }^{4}$ See U.S. News \& World Report, Feb. 27, 1967, at 68-69.
} 
sequelae to population growth may be noted. The first of these, the accentuation of population concentration or density, has already been touched upon. The second, increase in overall population, is treated largely under the head of population concentration, of which it is a source. Of course, enlargement of areas of population density outside areas of heavy concentration do produce effects of the sort discussed below, though less intense than those found in areas of heavy concentration.

The third effect of population growth is the absorption of inputs which might otherwise have been used to improve the material condition of the existing population and its replacement. Here we may indicate only the order of magnitude of this cost which may then be compared with fixed investment in residential construction that has been running about $\$ 22$ billion a year. If we conceive of capital only in terms of hard goods and suppose it costs about four per cent of the national income to support a rate of population growth of one per cent per year, then the cost of America's population growth has been in the neighborhood of $\$ 30$ billion a year since r964. If we include under the head of "capital" all expenditure which serves to increase the stream of income in the future and allow as well for the adverse effect of population growth upon the age composition of the population, we may raise this figure to around $\$ 45$ billion. Another way of arriving at an estimate is to suppose that the cost of adding a cross-sectional thousand people to the nation's population costs between \$1o and \$20 million. On this supposition, adding about 2.5 million persons a year to the population costs between $\$ 25$ and $\$ 50$ billion a year. Whatever be the correct estimate, it represents an annual expenditure far in excess of the current rate of expenditure upon residential construction. Of course, even should fertility fall to the replacement level, it would take a few years for the benefits to materialize fully and then they might be utilized in part in the form of leisure. ${ }^{46}$

The fourth effect is associated with the continual change in city size produced by population growth and discussed earlier. Let us suppose that a country's population is stationary. Its population distribution will then be fairly stable, affected by changes in technology, incomes, and the composition of tastes and amenities, but not by the main source of distributive change operative in the past-namely, increase in the nation's population. The urban problem would then become mainly one of keeping particular cities and their macro-habitats intact; it would thus resemble maintaining a stationary economy's capital intact. ${ }^{47}$ Financial provision for the maintenance of all components of a city including its housing and macro-habitats could then easily be put on an orderly basis. Planning for changes could be carried out readily since almost any particular change would be but a wave in a sea of stability. Short and long time-horizons would differ less than now. The remaining changes would be

\footnotetext{
${ }^{\text {so }}$ When families earn less than $\$ 6,000$ per year they tend to put forth extra effort. See Morgan, Serageldin, \& BaERWaidT, supra note 9, at Igr. See generally on choosing between more work and more leisure, id. at 198-202.

${ }^{47}$ See generally on "maintaining capital intact," A. C. Pigov, Economics of Welfare $43^{-49}$ (4th ed. 9932).
} 
small enough so that, were they met sub-optimally, corrective action would be easy and not very costly. Under these conditions demographic metabolism, the replacement of old families nearing or beyond retirement by younger families, would entail little unfavorable change in the quality of the environment.

Population concentration and density produce a number of somewhat distinct effects, all of which, when intensified beyond a critical point, outweigh the advantages associated with a lesser amount of population agglomeration. These effects are incident on some or all the macro-habitats constituting a community, though in varying degree, and they reduce the contribution that housing can make to welfare. "Welfare," in other words, may be viewed as a joint "product" of (inter alia) that which a household's housing and macro-habitat make possible and that which the larger, all-inclusive community makes possible. Agglomeration of population continues to increase the latter contribution after it has begun to diminish that of housing and habitat, until a point is reached where the positive effect is offset at the margin by the negative effect. This is the optimum point; it varies with household, of course, and this variation affects how population distributes itself within urban or metropolitan space.

It is not possible here to catalog and describe all the effects associated with excessive population growth and concentration, but the main ones may be touched upon in order to illustrate the theme of this paper. These effects are contraction of space, pollution, congestion, unproductive use of time, and sub-optimal distributions of population.

Population concentration reduces the ratio of space available per person for household and/or other activities and thus diminishes the contribution of space to the city-dweller's standard of life. In I 960 about twenty-eight per cent of the nation's population occupied only 0.23 per cent of its land area, and about forty-five per cent occupied just under one half of one per cent of this area. Population density ranged from 13,870 persons per square mile in places of a million or more to just over 3,900 per square mile in places of 50-100 thousand and about 2,290 per square mile in places of to to 25 thousand. Expressed in terms of acres per person, ground space per person ranged from about one twenty-fifth of an acre in places of over a million to one-sixth of an acre in places of 50-100 thousand and nearly three-tenths of an acre in places of ro-25 thousand. Even if we allow four persons per household, the pinch of space is pronounced, for part of this average land quota is required for streets, structures other than housing, and very rarely for parks. Moreover, since the daytime population of cities is much greater than their nighttime population, density within the city in daytime is more pronounced than our data suggest.

Second, population concentration increases the exposure of housing and macrohabitats to pollution of all sorts. Most of it is ultimately of human origin and therefore is in greatest amount where men are concentrated and live, work, and consume, and hence manufacture debris, pollutants, and contaminants of all sorts. 
Moreover, the impact of this unwelcome product is hard to cushion. For example, since about nine-tenths of United States air pollution "consists of largely invisible but potentially deadly gases," air conditioners cannot defoul the atmosphere; at best they can remove particles. ${ }^{48}$ It is doubtful, therefore, if man's natural right to breathe clean air can be made realizable in megalopolitan or other large centers. Indeed, he may find himself hard pressed even to dispose of his refuse and get a sufficient supply of usable water. ${ }^{48}$

We may state the problem generally and in terms of a set of hypothetical flows. Modern life is subjective and objective; it consists largely in symbolic communication and in the flow of men and matter. The volume of each stream tends to increase faster than population, especially in urban settings. Indeed, an urban center, above all, a megalopolis, may be thought of as a network of channels for the conduct of men and matter, together with information, within that center and between it and the world outside its environs. Channel capacities are limited and so are the number of channels actually or potentially available. Let $R_{e}$ represent the rate of flow of effluent $e$ and $C_{e}$ the capacity of channels existing for the conveyance and disposal of $\epsilon$ into the atmosphere, into waters, and elsewhere, but always in keeping with the health and good life of all concerned. If $R_{e}>C_{e}$, portions of $e$ must be destroyed at points of origin, or stored until $R_{e}$ falls below $C_{e}$. Otherwise $e$ will accumulate within the population center and perhaps in areas immediately nearby. Presumably $R_{e}$ grows at least as fast as $\left(p^{\prime}+g^{\prime}\right)$ where $p^{\prime}$ denotes the rate of population growth of an urban center and $g^{\prime}$ denotes the rate of growth of per capita consumption and/or production of output which gives rise to various forms of effluent within the urban center. Since $C_{e}$ has upper limits, it is inevitable that as a center's population grows, the probability of pollution of the macro-habitats of housing increases.

Third, congestion of channels for the conveyance of people and perhaps also of those for the conveyance of information tends to increase with population growth and concentration. Consider for example the movement of traffic through the center of a metropolitan area; it can grow nearly as the square of the population. "To keep the degree of traffic congestion constant, road traffic capacity must rise far more than in proportion with the rate of increase of population, and sheer problems of geography and land availability practically preclude such a possibility. Of course, the fact that population tends to cluster and is not spread evenly throughout the city only adds to these congestion problems." ing noise and disorder, tends to accentuate two interrelated forces which generate

\footnotetext{
${ }^{18}$ Ecology, TIME, Jan. 27, 1967, at 48, 49-50; See generally Restoring The Quality of OuR ENVIronMeNT, supra note 29 , at I-9, 62-69.

${ }^{10} \mathrm{New}$ York's garbage dumps will be filled in eight years. N.Y. Times, Feb. 20, 1967, at 27, col. I. See generally on the water problem, Wolman, The Metabolism of Cities, Scientific AM., Sept. r965, at 179, I8I-85.

so Baumol, Urban Services: Interactions of Public and Private Decisions, in Public Expendrure Decisions in the Urban Comiunity I, 7-8 (H. G. Schaller ed. I963).
} 
the cumulative deterioration of local environment and macro-habitats-namely, urban blight and flight to the suburbs. ${ }^{51}$ Dense traffic is not the only form of congestion that inflicts uncompensated costs upon a large fraction of the population. There is also, as Colin Clark points out, a second type, "zonal congestion," the dearth of open space for recreational and other purposes. ${ }^{52}$ Oddly enough, another British author argues for the "concentration of future population growth in a limited number of major cities as opposed to a balanced and uniform expansion of all existing urban centres." ${ }^{53}$ Such concentration will economize on land and thus preserve more land for agriculture and the amenities. ${ }^{54} \mathrm{He}$ has in mind England where overall population density is very high, greater even than in Japan.

Fourth, two further concomitants of population concentration may be noted, each of which may affect man's macro-habitat adversely. First, a population and its activities may become sub-optimally dispersed within a metropolitan region and then perpetuated because the totality of public and private fixed capital outlays undergirding this distribution is so great as to render modifications very expensive. Herein, it is to be noted, we find support for careful anticipational urban planning, together with emphasis upon the preservation of flexibility and the retention of options realizable in the future. Since urban decisions tend to become frozen in steel and concrete as well as in transport systems, they should not be taken and acted upon until and unless the future is relatively clear. Second, a sub-optimal distribution of population and activities makes for high consumption per capita of modern man's most precious possession, time that might otherwise be discretionary and hence contributive to his well-being. Perhaps increasing education will result in countervailing measures. Did not Dante write: "Who knows most, him loss of time most grieves." ${ }^{.55}$

\section{$\mathrm{V}$}

\section{Policy Implications}

Certain policy implications may be derived from what has been said. First, it is unlikely that the housing problem can ever be solved satisfactorily so long as population continues to grow and with it the excessive size of cities. For the impact of growth, unless carefully planned for and counterbalanced, will make for continual decay of parts of cities and hence of macro-habitats. Not only central cities but suburbs as well will continue to be subject to this process of decay which steals in unobtrusively, not as a fast-working pestilence that comes in the night but as a slowly working mutagen which produces a bodily change that in time metastasizes.

\footnotetext{
${ }^{51}$ Id. at ir-14; G. Neutze, Economic Policy and the Size of Cities (1965).

62 Clark, Industrial Location and Economic Potential, Lloyps Bank Rev., Oct. 1966, at r, 3-4.

${ }^{53}$ Bellan, The Future Growth of Britain's Cities, 37 The Town Planning Rev. 173, 183 (1966).

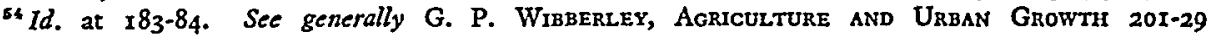
(1959).

${ }^{55}$ PURGatory, Canto 1.
} 
It will probably be many years, however, before population growth ceases, or, in the absence of nuclear war, becomes negative.

Second, contemporary tax and subsidy systems conduce to the deterioration of many macro-habitats, together with housing, by putting a premium on deterioration or by shunting its costs from those responsible to non-responsible third parties. (a) Buildings and land need to be differentially taxed in order that taxation of real property, usually a deterrent to its maintenance and improvement, will cease to be so. ${ }^{56}$ (b) Every business firm or organization must be made to bear all congestion and related costs to which it gives rise, costs currently borne in part by others. (c) Impose the entire cost of urban expansion upon those responsible for this cost, instead of partly upon non-responsible parties as at present.

Third, current financial arrangements for maintaining housing and other forms of urban capital are inadequate to keep this capital intact through repair and/or replacement. Two approaches seem indicated. (I) Requiring the accumulation of adequate, earmarked liquidable assets to permit repair or replacement as it becomes necessary. (2) Require architects to plan construction in much greater measure than now in terms of easily replaceable parts, a point insisted upon by A. Spilhaus in his plan for an experimental city of about $250,000 .{ }^{57}$

Fourth, many problems associated with urban growth and housing flow from inattention to the need to balance total costs and benefits at the margin; and this form of inattention tends to grow faster than the size of urban centers. Pollution, congestion, and related costs are among those that need to be offset. A variety of measures is available for this purpose, some of which are better suited than others to particular cases. ${ }^{58}$

Fifth, several implications follow from the irreversible character of decisions or processes determining urban growth after it has taken place. It sometimes happens, as Lösch has pointed out, that production, having been initiated in the wrong place, will be continued there. ${ }^{59}$ For such mislocation imperfectly planned investment is responsible. Urban growth and extension entail heavy fixed-capital investment the sacrifice of which, along with that of economy-yielding business connections, makes decision-makers loath to shift location. Given this heavy ex-post anchor, should not ex-ante decision-making be forced to take into account all expected costs as well as all suppositious advantages? Should not the set of forces

\footnotetext{
${ }^{10}$ M. M. Gaffney writes of building taxes as distinguished from land taxes that "it would be hard to contrive a tax calculated to throw more risk onto the builder in proportion to the revenues raised." Gaffney, Property Taxes and the Frequency of Urban Renewal, in Proceedings of the Fifty-Seventh Annual Conference on Taxation 272, 284 (National Tax Ass'n I964). The builder responds by not making improvements since the assessment of his land moves with the assessment of the structure on it. If, however, land is assessed and taxed at its true opportunity cost, it can no longer be economically allocated to sub-optimal uses. See id. at 272-85. See generally Woodruff \& Ecker-Racz, Property Taxes and Land Use Patterns in Australia and New Zealand, The TAX Executive, Oct. 1965, at 16.

${ }^{87}$ Spilhaus, The Experimental City, The News and Observer (Raleigh, N.C.), Jan. 22, 1967, \$3, at I.

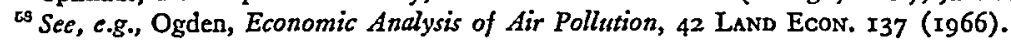

is A. Lösch, The Economics of Location 258, 330-3I (1954).
} 
currently shaping city growth be brought under more effective control, at least so long as these forces resemble those governing the growth of polyp colonies? Of course, city size could be explicitly limited, and the ownership of all urban land could be vested in cities. Such controls might, however, run counter to economic flexibility and American ideology. The same objectives could probably be achieved through use of a system of taxes and subsidies, calculated to influence population distribution and provide compensation to those on whom discretionary decisionmakers imposed unrequited direct and indirect costs. These tax and subsidy arrangements would be reinforced if a rent-absorbing tax in keeping with, say, the zonal opportunity cost of land were imposed on all land in and around cities.

Sixth, perhaps the greatest promise lies in the development of an adequate number of additional cities of such size-say, I00-200 thousand-as provides adequate communal opportunity, together with near-optium conditions for housing and macrohabitats as well as abundant access to amenities and recreational space. Suppose that 600 such cities were established during the next thirty-five years. They could absorb $60-90$ million or more inhabitants, or something like $60-80$ or more per cent of the prospective population increase, most of which will settle in urban centers. If, say, as much as one-fourth of the population absorbed into these cities were nonwhite, it is possible that more than the anticipated increase in the nonwhite population would be settled there; then the current drift into central cities and ghettoes would be checked and perhaps reversed. Should such cities not be established, the population of most cities now over ro0,000 would be greatly increased, for the next thirty-five years will witness the addition of 100 or more million to this nation's population and perhaps that of an equal number to the urban population, which in rg6o already numbered II 3 million on the old census definition and I25 million on the new definition.

That this promise is realizable is suggested by two facts: (a) the relevant Key Decisions regarding location and many other matters are made by a very small number of business men; (b) big business men and corporations are becoming increasingly interested in the development of attractive, rationally-organized cities. We may divide a working population into Primary Job Makers and Job Takers, in which category may be placed Secondary Job Makers. The Primary Job Makers establish and locate the basic enterprises and employments. Around these gather Secondary Job Makers whose enterprises service and meet the needs of the Primary Job Makers and their employees as well as those of all persons who fall in the JobTaker category. The heads of some but not all governmental agencies and foundations belong in the Primary Job-Maker category as they make Key Decisions affecting location of activities.

(a) That the making of Key Decisions respecting location is highly concentrated is suggested by the following data. In 1965 twenty-one out of each roo persons $\mathrm{em}$ - 
ployed in the United States were employed by $75^{\circ}$ companies, many of which are describable as Primary Job Makers. About 55.I per cent of all industrial workers were employed by 500 industrial companies. ${ }^{60}$ Brian Berry reports that in the area around Chicago the location decisions of about twenty retailers control those of about 20,000 lesser retailers respecting where they will carry on for the next twenty-five years. ${ }^{61}$ It is evident, therefore, that the Key Decisions essential to locating basic employment in new cities may be made by a small number of business firms. The implementation of such locational decisions would entail a redistribution of "brains," now most unevenly distributed because of unequal distribution of economic activities and educational institutions. ${ }^{62}$ For "brains" have not merely replaced muscle; they now constitute the most strategic form of mobile and creative capital. "Brains," however, insist on access to cultural and other amenities as well as to good housing and attractive macro-habitats. Of this Key Decision Makers are becoming increasingly aware even if the current urban power structure is not.

A Key Decision Maker or two can launch a new city destined to number 100-200 thousand inhabitants by establishing an economic base capable of multiplying and expanding into around $40-80$ thousand jobs. ${ }^{63}$ If such base is established, say by introduction of manufacturing plants that employ ro-20 thousand persons, the labor force will expand sympathetically to something like 40-80 thousand gainfully employed. Manufacturing is not, of course, the only possible source of an initiating economic base, particularly in the United States where the ratio of employment in manufacture to all employment is falling. Other activities, among them collections of services, may provide a base; they need only to supply the exports that enable the community to purchase goods and services not supplied locally.

(b) A Key Decision Maker may be interested in doing more than locating activities at a point in space where, he believes, a city with attractive environs will come into being. He may want to establish a more complete city, one providing not only basic employment but also ordered and abundant space for all ancillary activities and amenities (including even such activities as amateur theatricals and similar activities which seldom yield returns even equal to private monetary costs). In such a city far more than in those described under (a) high priority must be given to housing and its macro-habitats and to averting the diverse costs and dissatisfactions associated with both life in central cities and life in isolated suburbs. Otherwise the collection of houses and macro-habitats constituting this city will not prove convertible into

\footnotetext{
${ }^{\circ}$ Big Business in American Society, Is lt Really Taking Over?, Business in Brief (Chase Manhattan Bank), Oct. Ig66.

- 1 North Estrern Illinois Planning Comaission, Metropolitan Planning Guide Lines, ComMercial Structure 94, cited in Clark, supra note 52, at 3.

'See Lapp, Where the Brains Are, Fortune, March 1966, at 154 .

is In $1960,40 \%$ of the population was in the labor force. Given lower fertility this fraction might rise slightly.
} 
a community that generates a degree of loyalty and collective responsibility. It is probable that planned cities of this sort, together with those referred to under (a), can absorb most of the prospective increase in urban population. Illustrative of the planned type of community is that near Clear Lake, Texas, sponsored by the Humble Oil Company and the National Aeronautics and Space Administration, and intended to evolve over a fifteen-year period into a city of some 140,000 residents living in some 40,000 houses situated in an area of twenty-four miles square that includes a 365 acre town center and a r,000 acre research park. ${ }^{84}$ Somewhat similar cities are planned by General Electric Company, Goodyear Tire and Rubber Company, Westinghouse, and other large corporations. Several are well along-Robert Simon's Reston, Virginia, intended to house about 75,000 people, and James Rouse's Columbia, Maryland, intended to house about Iro,000 people. All follow Secretary Udall's advice that "city planning should put people first."

The types of towns referred to have a localized primary base, supplemented in several instances by the activities of inhabitants destined to work in nearby metropolitan centers. The housing problem is solved, though sometimes at the expense of considerable cost in potentially discretionary time. This time-cost must be borne also by some of those who live in small planned communities (other than retirement communities) situated near metropolitan centers to which many must journey daily for employment. Again, however, the housing problem is solved.

\section{Conclusion}

The argument permeating this essay is that the housing question must be examined and carried toward resolution through a systematic approach rather than through the piecemeal approaches of speculators and others who neglect the fundamental importance of macro-habitats and their relations to each other and the larger urban unit. This approach is of increasing significance in an age when discretionary time is increasing and the challenge of the inept may be undergoing intensification, perhaps with Toynbeean implications. ${ }^{66}$ It is not inferred that improvement in housing or even in macro-habitats will solve the ills of the day though it may contribute to solutions under appropriate conditions. It is suggested, however, that we are in need of innovation of systematic though diverse arrangements suited to the housing, habitat, and related needs of communities of varying size and situation. It is emphasized finally that our capacity to meet these needs is likely to be inversely related to our rate of population growth.

\footnotetext{
od The Birth of a City, The Humble Way, No. 4, 1963, at 1-3.

${ }^{\circ} S$. L. Udali, The Quiet Crisis I7o (1963).

${ }^{\circ}$ See Goode, The Protection of the Inept, 32 AM. Sociorogical Rev. 5 (1967). See generally on the internal proletariat, 5 A. ToynbeE, A Study of Hisrory 58-194 (1939).
} 